\title{
An Analysis of the Concept of "People-Oriented" Modern Education Management
}

\author{
Xinghao Wang ${ }^{1, *}$ \\ ${ }^{1}$ School of Humanities and foreign languages, China Metrology University, Hangzhou, Zhejiang, 310018, China \\ *Corresponding author. Email: dfxinghao@foxmail.com
}

\begin{abstract}
With the continuous deepening and development of modern education management concept, China's education has enhanced the understanding of the value of humanistic education, and constantly shows the humanistic spirit in theory and practice. But in education management, the school has always been teachercentered, ignoring the development of students' subjectivity and personality. This paper not only emphasizes the subjectivity of students in the "people-oriented" education concept, but also expounds some specific theories and practices of the "people-oriented" education management concept in modern education management.

\section{Keywords: People oriented, humanistic education, modern education management, management concept}

With the continuous development of society, people have different understanding of the concept of education management in different periods. In today's society, from the state to the school and then to the individual students, the concept of "human oriented" education management is emphasized. Humanistic management is an important feature of modern education management. Starting from the humanistic spirit of "people-oriented", education administrators, teachers and students managed can not only better promote each other's development, but also be more conducive to the development of education management.

\section{AN ANALYSIS OF THE CONCEPT OF "PEOPLE-ORIENTED" MODERN EDUCATION MANAGEMENT}

In order to carry out the concept of "people-oriented" in modern education management, it is necessary to understand the two subjects involved in "people-oriented" in education management, namely, teachers and students. Therefore, it is necessary to take the "teacher" as the basis of education management and the "student" as the basis of education management.

\subsection{Student-centered learning}

The work of education is to cultivate students. The core of education is to teach and educate people. Education is the foundation, teaching is the means and method. All along, we have been advocating respecting teachers and valuing their teaching ability and personal moral level. Therefore, in education management, teachers and students are the relationship between the manager and the managed. However, to a large extent, it limits the personalized development of students, mainly teachers. Although each student has received the same education content, it cannot guarantee that each student can fully absorb the knowledge. The relationship between teachers and students should be equal, and "student-centered" means that teachers should fully respect and understand students ${ }^{[1]}$ In strict management of students at the same time, but also to enable students to give full play to the subjective will.

\subsection{Take "teacher" as the Foundation}

The fundamental duty of the classroom is to educate students. Teachers are not only the main body of education, but also the main body of education management. The ancients said that "a strict teacher leads to a good apprentice". The education level and moral level of teachers have always been valued by the society. To advocate "Teacher-centered" is to emphasize the moral level of teachers themselves, so that they can constantly know themselves and improve themselves in the actual educational management activities.

The school is the place of education, so the school should cultivate a good atmosphere of respecting and loving teachers, care for teachers in life and education activities, so that its own teaching management is not affected by external interference, the whole society should also increase the support for teacher training. School administrators should formulate a reasonable assessment and reward mechanism according to the actual situation of the school. Each school should take the effectiveness of teachers' practical education as an important indicator to measure the quality of school running, formulate scientific and perfect assessment and evaluation methods, and regularly evaluate and commend advanced collectives and individuals who have outstanding performance in publicity and education management. Here, the assessment of instructors mainly lies in the completion of their teaching 
work and education management. And the feedback of students on their work in practice.

\section{THE APPLICATION OF "PEOPLE- ORIENTED" MODERN EDUCATIONAL MANAGEMENT CONCEPT}

\subsection{Cultivate Self-management Awareness}

"People oriented" should not only be student-oriented, but also teacher oriented. In modern education management, it needs the joint efforts of teachers and students to implement humanistic spirit into specific education management. Teachers should cultivate students' selfmanagement concept, let students play their own initiative in educational management activities, help students establish self-management awareness, and guide students to manage themselves ${ }^{[2]}$ Teachers should also establish a good management system and feasible methods, carry out self-management with students, set an example for themselves, reflect on themselves and develop themselves in the process of cultivating students. Finally, a win-win situation will be achieved.

\subsection{Respect Students' Creativity}

Everyone is different, although the teacher is in front of many students, but cannot ignore the subjectivity of the students themselves. Confucius said: "three people, there must be my teacher Yan." Although the students' world outlook and values have not been fully established, the teacher should be student-centered in the education management, and also be able to find a place to learn from the students, respect the students' creativity, affirm the students' ideas on the one hand, and enhance the students' self-confidence and subjective consciousness on the other hand. Teachers and students learn from each other and make progress together to create a good educational management situation and an equal exchange environment.

\subsection{Caring for Teachers}

In real life, teachers also have their own life, also have their own joy, anger, sadness, joy, in life will encounter some troubles and difficulties, teachers should also be concerned and loved. School leaders should pay more attention to teachers, actively understand the suffering and development needs of teachers, try their best to comfort and encourage teachers, let teachers correct their attitude, and face the contradiction with optimistic and openminded attitude. So that teachers can feel the care and care of the school, teaching at ease. The establishment of a sound teacher's teaching guarantee mechanism requires schools to provide at least three powerful guarantees. The first is the guarantee of the system: the system is fundamental, overall, stable and long-term, and the establishment of a long-term mechanism of teacher's guarantee in schools must be assigned to relevant rules and regulations; The second is fund guarantee: we should include the fund for teacher guarantee and education in the special budget, and ensure the necessary expenses for carrying out teaching activities, such as publicity, transportation, accommodation, rewards, labor and so on, In order to provide funds for the smooth development of teachers' management and teaching activities, there is also a team guarantee mechanism: we should strengthen the training of guidance teachers, improve the comprehensive quality of teachers, and select teachers with outstanding ability and strong sense of responsibility.

\section{THE EMBODIMENT OF HUMANISTIC EDUCATION IN MODERN EDUCATION MANAGEMENT}

The idea of "people-oriented" should highlight the humanistic spirit, that is, to strengthen the humanistic education from school to teachers. The reform of modern education management should embody the humanistic spirit. Modern education is based on the development of people, starting from people themselves, and using "heart" to understand, treat and care for people. [3] Whether from the actual needs of education, or from the theoretical pursuit of education; whether from the requirements of the development of human nature, or from the transformation of modern education methods, people-oriented is the inevitable requirement of modern education. Therefore, humanistic education meets the needs of modern education management.

\subsection{Humanistic Education Meets the Needs of the Development of the Times}

China is a country with a large population. After more than 40 years of reform and opening up, we have become a country with talents. The development of modern education needs people-oriented education to adapt to it, which is the need of social development. At present, as the main mechanism of knowledge dissemination and creation, the value of education will be improved unprecedentedly. In modern society, people's subjectivity is constantly recognized, and people's own value is constantly reflected. Today's society has got rid of the previous situation that one person can complete the research and development of core technology, and has entered the stage of group joint efforts.[4] Therefore, taking innovative knowledge as the core, cultivating innovative talents will become the primary task of education. The necessary condition for cultivating students' innovative ability and innovative spirit is to integrate humanistic spirit into education, from the traditional emphasis on knowledge accumulation to the emphasis on intelligent development. Without humanistic education, it is difficult for Simple Science education to 
independently complete the task of intelligent development.

\subsection{Humanistic Education Meets the Needs of the Development of Quality Education}

In essence, quality education is the return of the most basic function of education, that is, the concern for people. Innovation is the soul and core of quality education, and the premise of innovation is to break the shackles of traditional education on human nature, reshape the humanity of education, establish the education concept of respecting students' personality, independence and creativity advocated by humanism, and create a safe and democratic learning atmosphere for students. As Maslow pointed out, creativity is more caused by personality and is a by-product of self-realization of personality. Quality education requires that the focus of education administrators shift from teacher education to students, so that students' personal character and value can be displayed, and people can communicate with each other, including the teaching of knowledge content, the understanding of life connotation, and the regulation of will and behavior, And through the function of cultural transmission, the cultural heritage will be passed on to the younger generation, so that they can freely generate knowledge and wisdom, and enlighten their free nature. It is an important goal of quality education to strengthen the humanity of education and make students develop good humanity quality.

\subsection{Humanistic Education Meets the Development Needs of Curriculum Reform}

Curriculum reform is to find out the shortcomings in educational management activities, get rid of these problems, so that modern education can be well carried out, so that modern educational management can play its highefficiency and high-level management function. The content of curriculum reform should fully reflect the spirit of humanistic education. Such as changing the traditional curriculum too much emphasis on learning, rote learning, mechanical training, advocating students' active participation, diligent in hands-on, cultivating students' ability to collect and process information, the ability to acquire new knowledge, the ability to analyze and solve problems, and the ability to communicate and cooperate. ${ }^{[5]}$ These contents are also reflected in Rogers, another educator. Rogers opposes the traditional understanding of the function of teachers, and believes that in this changing modern society, "the primary task of a teacher is to allow students to learn and allow him or her to satisfy their curiosity." He pointed out that the standard to measure a teacher's excellence is "to see how creative he or she is to promote learning and to maintain or stimulate students' love for learning". Error! Reference source not found.Rogers also believes that whether a teacher can become a promoter of students does not depend on his teaching ability, but mainly depends on his attitude when dealing with students. ${ }^{[6]}$ That is to say, teachers or education administrators should respect students and the managed, treat students and themselves sincerely, and communicate equally. No matter how students perform in daily life, teachers should actively pay attention to the growth of students and express their care and love from the heart. Teachers should respect students' personality, curiosity and creativity, and help students develop their creativity and pioneering thinking ability.

\section{CONCLUSION}

With the development of society, "people-oriented" has gradually become the core concept of modern education management, and "people-oriented" spirit has gradually gained consensus in the whole society. In teaching or education management activities, the humanistic spirit is constantly deepening in the hearts of teachers and students. In this paper, the two main aspects of people-oriented concept - "teachers" and "students" as the starting point of analysis.

The text of "teacher" should care for teachers and establish a perfect guarantee mechanism for teachers; the text of "student" should respect students' creativity and cultivate students' consciousness of self-management. Only in this way can we realize the "people-oriented" modern education management and promote the improvement of the overall level of education management.

\section{REFERENCES}

[1] Zhao Weixiang. Practice analysis of modern "people oriented" educational management thought [J]. Knowledge base. 2019-11.

[2] Li Yun, a preliminary study on the concept of "people oriented" education management [J] curriculum education research, August 11, 2017

[3] Bao Xiaoling, the penetration of people-oriented concept in higher education management $[\mathrm{J}]$, science and education guide, November 25, 2020

[4] Xie Bili, application of humanistic concept in Higher Vocational Education Management [J], tourism longitudinal, December 23, 2019

[5] Zhuang Jiayuan, on the innovation of higher education and teaching management should be peopleoriented $[\mathrm{J}]$, science and technology economy guide, December 25, 2019

[6] Jaden's cognition and Thinking on the establishment of a people-oriented university teaching management system [J], international public relations, October 15 , 2019 